\title{
Deák Dánıel
}

\section{Mll a magyar most?}

\section{Hozzászólás Hadas miklós esszéjéhez}

Nem veszélytelen vállalkozás nemzetkarakterológiáról beszélni, mert belefulladhatunk a „magyar faj” hírhedett terminusával terhes csökött nacionalizmusba. A szociológia közismert felfedezése ugyanakkor Alfred Schütz, sőt már Durkheim óta az, hogy a társadalmi tagozódás nem írható le csupán objektív kategóriákkal: legalább annyira fontos azt vizsgálni, hogy az érintett társadalmi csoportok miként tudatosítják, illetve magyarázzák saját helyzetüket. $\mathrm{Az}$ is a szociológiai tudás része azonban, hogy az életvilág belakásának színtere a kisközösség.

Miközben jelentéssel bíró lehet, ha vizsgáljuk a társadalmi gyakorlat szubjektív vetületét - amikor beállítottságokra, hajlandóságokra, ízlés- és értékpreferenciákra, késztetettségekre, motivációkra, érzületekre kérdezünk rá -, kutathatunk strukturálisan kondicionált viselkedésminták után is, amikor objektív magyarázatot keresünk. E minták megértése csak akkor lehetséges, ha azokat történetiségükben ragadjuk meg. Ezért amikor a továbbiakban (újból) feltesszük a „mi a magyar most?” kérdését, a távoli és közelmúlt történelmét azért magyarázzuk, hogy saját társadalmunkat jobban megérthessük. Valóban értelmes előfeltevésnek látszik - ahogy Hadas Miklós teszi - hosszú távú történeti logika alapján felvázolni a visszatérő intézményi struktúrákat, történetileg kondicionált habitusokat és az ily módon valószínűsített társadalmi gyakorlatokat, majd az ezek által meghatározott reprezentációk és objektivációk főbb sajátosságait.

Hadas Miklós esszéje annak átgondolására késztet bennünket, hogy időszerüek-e még a magyar kultúrában általános tiszteletnek örvendő gondolatok: a nemzeti jelen szembeállítása a dicsőnek mondott múlttal (Berzsenyi, Kölcsey, Vörösmarty), miközben a jövőt illetően be kell érnünk homályos célzásokkal, kitéve magunkat a sorsszerü forgandóságnak (Faludi, Berzsenyi). Hűvös ésszel meg kell kérdeznünk: vajon létezett-e a múltbeli dicsőség? Nem inkább arról van-e szó, hogy jelen bajaink szervesen következnek a múltban kialakult problémákból? 


\section{Megemésztetlen múlt, régi és új traumák}

Nincs sürgetőbb feladat, mint válaszokat keresni arra, mi történik ma Magyarországon, hogyan veszíthettük el a harmadik köztársaságot, és hogy mi ebben az értelmiségiek felelössége. Ezért üdvözölhető Hadas Miklós kísérlete, és ezért jó, ha közzétett gondolataihoz hozzászólhatunk. Keserüséggel kell megtapasztalnunk, hogy ismét csalódtunk reményeinkben, és végzetesen eltávolodtunk - ki tudja, meddig? - Mészöly Miklós derülátásától:

Ma ismét felbátorodva gondolhatjuk, hogy társadalmunk - legalábbis a sorsdöntő gesztusait tekintve - végérvényesen más már, mint ötven éve, mikor a kollektív önterápia, a „belső leszámolás" hiánya olyan tragikusan sodort valamennyiünket bukásba; a még mindig nem kellőképpen ki- és bevallott mocsokba. A mostani március 15. hangulata, fegyelmezett és emelkedett radikalizmusa, a megtisztított szavaknak, fogalmaknak ez a maradandó parádéja - erősen hiszem - a lelkiismereti öntisztulás elmaradt gesztusainak megtételéhez is közelebb vitt bennünket (Mészöly 1990: 303-304).

Mészöly 1989-es meglátásával ellentétben ma úgy kell látnunk: nemhogy végérvényesen szakítottunk volna 1939 vészterhes örökségével, hanem közéletünk visszazuhant egy olyan állapotba, amelyben sorra felbukkannak a megidézett vészterhes időszak kísérteties rögeszméi, és ennek a zuhanásnak az oka éppen az, hogy megint elmulasztottuk véghezvinni a Mészöly által elvárt kollektív önterápiát.

Bár Hadas Miklós esszéjének nem minden premisszájával lehet feltétlenül egyetérteni, a mủ a folyamatelemzés jó példáját nyújtja attól függetlenül is, hogy a megfogalmazott téziseket valaki maradéktalanul osztja-e vagy nem. Itt-ott lehetne a hangsúlyokat máshová tenni, ami azonban természetes, hiszen még ha sokan hasonló szocializáción mentünk is keresztül, mindannyiunk a maga külön életét élte, illetve éli. Így például meglepő és további kifejtésre szoruló állításnak gondolom azt, hogy a három vizsgált modernizációs korszak esetében a Kádár-korszak szembeállítható a Horthy-korszakkal és az Orbán-korszakkal abban, hogy míg utóbbi két esetben a rendszer felbomlása és önpusztítása kódolva volt, illetve van, addig a Kádár-rendszernek lett volna egy konszolidációs kifutása. Ilyen részpályák talán leírhatók benne, de alapjában véve az államszocializmus termelőstruktúrája is kezdettől fogva magában hordozta az összeomlás lehetőségét. A dualizmus korával kapcsolatos derűlátást sem osztom maradéktalanul. Legyen elegendő itt csupán Babitsra utalni, aki - egy nemzedéknyi távlatból - a korszak hőseinek ezt a nevet adja: „halálfiai”.

Indokolt törekvés a felvázolt beállítottságok, kánonok, viselkedési mintázatok és jellemző cselekvési stratégiák mint történetileg változó jelenségek elemzése, mert ezek megragadásával juthatunk közelebb annak tudásához, hogy milyen világban élünk itt és most Magyarországon. Ebben az összefüggésben pontos, szemléletes és a jobb megértéshez igen hasznos Hadasnak például ez a megállapítása, mely szerint „...az új elit nem rendelkezik sem az arisztokrácia becsületkánonjával, sem a polgári középosztály erénykánonjával, sem az alsó osztályok (mindenekelőtt a parasztság) nélkülözésen edződött, fegyelmezett és alázatos munkakánonjával” (Hadas 2017: 201).

A Hadas-tanulmány címében föltett kérdés (mi a magyar?) először is arra irányítja figyelmünket, hogy 2010 óta az állami berendezkedésben döntő fordulat ment végbe Magyarországon. A hatalom birtokosai az alkotmány alanyává a politikailag szervezett nemzetet tették, leértékelve ezzel az egyént, megfosztva a polgárt a személyt megillető feltétlen méltó- 
ságtól. Sorsunkat máig meghatározza az, ami az emelkedő nemzet 1956-ban történt kivételes mozzanatában ment végbe, hogy ti. a forradalomba átváltott felkelés olyan szabadságharcba torkollott, amelynek tétje nem a polgári, hanem a nemzeti szabadság kivívása volt. Nem sikerült a magyar társadalomnak meghaladnia a zsákutcás fejlődésből adódó korlátokat. A felkelők cselekvése nem irányult a politikai szabadság teljességére:

Ennek a forradalomnak a szabadságeszménye leginkább a tizenkilencedik századi, a negyvennyolcas szabadságeszményhez kapcsolódott, de nem a párizsihoz, nem a bécsihez, hanem a pestihez, s így inkább magyar függetlenségi mozgalomnak tekinthető és nem szabadságmozgalomnak, mert szabadságeszménye nem a személyes szabadság, hanem a nemzet szabadságának eszményéhez kötött. Szabadságmozgalom, de nem polgári szabadságmozgalom, a szabadság eszményét nem a személy szabadságához, nem a szabad személyek társulásához és jogi eszményeihez köti, hanem a nemzeti függetlenség kívánságához (Nádas 2017: 588-589).

A nemzetkarakterológia és makrocsoportok leírása csak nagy vonásokban lehetséges, ezáltal elmosódott képeket kapunk, amelyeket helyenként árnyalni szükséges. Így például nem gondolhatjuk, hogy a rendszerváltozások után csupán parvenü elitek kerültek volna uralmi pozícióba. Az első világháborút követő konszolidáció a hagyományos elit müve, a fehérterror - bármilyen visszataszító volt is - a rendszer megszilárdulása szempontjából csak közjáték, és a Gömbös-féle „condottiere” típusa csak a harmincas években jelenik meg. Vagy napjainkat nézve, ma is vannak még olyan társadalmi erők, amelyek képviselői elhatárolódnak a felemelkedő Orbántól és társaitól, és ezért Orbánra akár a nyilvánosság előtt is úgy lehet rámutatni, mint egy Gömböshöz hasonlító figurára, mint egy pojácára (un pagliaccio). A Kádár-korszakot illetően pedig fontos megértenünk, hogy a hatvanas évek végén az értelmiség osztályhatalommá válik, mert kiegyezés megy végbe a hatalom és az értelmiség között, utóbbi bekerül a hatalom sáncain belülre, és sajátos módon képessé válik a maga értékeit az államszocialista rendszer keretei között előtérbe helyezni.

A legutóbbi rendszerváltozás végigvitelében jelentős szerepet játszottak az ún. alámerülők, ami egyébként meglepetés volt a történelemismerők számára is. Nem gondoltuk volna ugyanis, hogy negyven év módszeres pusztítása után képes a dzsentrimentalitás feléledni. Ennél sokkal fontosabb: felmérések szerint a rendszerváltoztatás fö erejét képezik az államszocializmus keretei között decentralizált vállalatok felső vezetői, vagyis éppen azok az értelmiségiek, akik bevonultak a hatalomba a Kádár-korabeli pártelittel való kiegyezés során. Ne feledjük: a szükséges intézményi változások (kétszintű bankrendszer, piackonform adórendszer, gazdasági társaságok alapításának szabadsága, egyesülési szabadság) a reformértelmiségnek köszönhetően már hiánytalanul készen voltak a Németh-kormány intézkedéseinek köszönhetően. A természet- és lélekromboló patriarchális társadalomszervezési logika és a parvenü elit folyamatosan jelen van persze, 2010 után pedig ezek a tendenciák hallatlanul felerösödtek.

Hasonlóképpen érdemes árnyalatokkal kiegészíteni a gyülöletideológia szerepéről kifejtetteket. Nem kétséges, hogy a maszkulin agresszióból következően a kirekesztés és a gyülöletbeszéd folyamatosan jelen van a modernizációs zárványoktól szenvedő újkori magyar történelemben, de azt is fontos hangsúlyoznunk, hogy változó intenzitással. Abból, hogy napjainkban a gyülöletpropagandát maga a legitim kormány szervezi, nem következtethetünk vissza, mert vannak békésebb, nyugodtabb korszakok is. A jelenben megtapasztalt gyülöletkultusznak sajátos, és korábban nem létezett okai is vannak az általános frusztráltságon 
túlmenően. Például ilyenek: a globalizálódás fokozódása, a társadalmi egyenlőtlenségek feltűnővé válása, a digitális kultúra elterjedése és a virtuális valóságok erőteljesebb megnyilvánulása, s ezzel összefüggésben a hamis hírek keveredése a valós információkkal stb.

\section{Strukturális bajok}

Az Orbán-rendszer urai törvényesítették a szociális kirekesztést azzal, hogy megvonták a magyar polgároktól az elemi szociális ellátáshoz való hozzáférés alanyi jogát, megsértve ezzel azt a polgári társadalomban rögzült normát, hogy a társadalmi különbségek elismerésének előfeltétele az alapvető szabadságok biztosítása minden egyes polgárnak. A pozitív módon megmutatkozó szabadsághiány kiegészül a negatív szabadsághiánnyal: a magyar állam polgára ma már nem kap intézményes biztosítékot arra, hogy állami beavatkozást csak abban az indokolt esetben kell elszenvednie, ha az adott állami szervnek intézkedésére kifejezett törvényes felhatalmazása van.

A múlt század nyolcvanas és kilencvenes éveinek fordulóján lejátszódott rendszerváltozás felemás eredménnyel járt: az állami vállalatok piacvesztése miatt kényszerűen végigvitt privatizáció következtében magyarok milliós nagyságrendben veszítették el munkájukat. Életük fenntartása másként nem volt lehetséges, mint hogy belesüllyedtek a szürke zónás gazdaságba: többségüknek sikerült igen szerény szinten legális megélhetést találnia minimálbéren, a mégoly szerény életvitel fenntartásához azonban a feketegazdaságból való merítésre volt szükség. Ez a máig fennmaradt szürke zónás létezési mód rombolja a munkakultúrát, lehetetlenné teszi a szolidaritást és elrabolja a jövőt, hiszen nyugdíjkilátásokra fedezetet csak a minimális mértékü legális jövedelem teremt. Miközben a felelőtlenség társadalmi méretüvé vált, a társadalom kiszolgáltatta magát politikai kalandoroknak, és magára szabadított egy minősíthetetlenül alacsony színvonalon müködő politikai osztályt.

A magyar karakter torzulásait észlelve érdemes a strukturális okok után kutatni. Hivatkozhatunk Preobrazsenszkijnek az eredeti szocialista (államkapitalista) felhalmozásról szóló törvényére. Ennek lényege, hogy a modernizációban megrekedt Kelet-Európában az adott társadalmi termelőstruktúra fenntarthatóságának előfeltétele az állam és a társadalom, a politika és a magánosok törekvései közötti antinomikus viszony. Ennek lehetséges oka viszont a Julio Olivera által leírt ciklikusság abban az értelemben, hogy nincsenek intézményes fékek a hatalmi koncentráció megállítására, egy ponton túl azonban elfogynak a fizikai és pénzügyi erőforrások, a társadalom kifárad, és akkor jön a kényszerü és ideiglenes visszarendeződés, hogy azután megint újrakezdődhessen a központosítás. A ciklikusság pedig végső soron magyarázható azzal, hogy a puha költségvetési korlát - Kornai értelmében véve - mikrokategóriából makrokategóriává válik: a politika által foglyul ejtett gazdaságban és társadalomban minden cseppfolyós, nem lehet tudni, mi a jó és rossz. Ezek olyan strukturális elemzési szempontok, amelyek megalapozhatják az adott körülmények között kialakult anyagi kultúra (beállítottságok, demográfiai mozgások, alapértékek, elöítéletek stb.) leírását és magyarázatát.

A társadalmi harmónia akadálya a konfliktusos társadalomkép és az együttműködés széles körü elutasítása. A követendő minta a polgári társadalom és a politikai állam funkcionális elkülönülése lenne, amelynek gyümölcseként kibontakozhatnak a polgári szabadságok - ehelyett azonban a valóságban a humán szférák alárendelődnek a szűk látókörű gazdasági 
igényeknek, a politikai önzésnek és az obskúrus ideológiáknak. Ugyancsak jellemző a múlt és a jövő manipulálása, a politikai ígéretek jövőbe való kitolása vagy éppen manapság a jövő iránti érzéketlenség, a humán szféra leértékelése szélsőségesen elitista állami beavatkozás révén, annak a hamis lehetőségnek a megjelenítésével, hogy a szélesebb jólét a jövőben helyreállítható egy magasabb szinten.

A gazdasági siker nem fejeződhet ki nyíltan, a gazdaság alárendelődik a gazdaságon kívüli kényszernek, informális döntési módok uralkodnak el. Lényegében még azt sem mondhatjuk el, hogy korrupció lenne, mert a baj nagyobb. A korrupció a polgári gazdaság normáinak kijátszása rejtett egyéni előnyök érdekében. Ahol azonban nincsenek polgári normák, ott nincs mit megsérteni: csak ügyeskedés van, és a szabályok megkerülése az általános. Nincsenek világos jogok és kötelezettségek, vannak viszont tagolatlan fájdalmak és milliós nagyságrendben leszakadó társadalmi csoportok.

\section{Magyar bajok}

Ha a magyar társadalom hátramenetéből többet meg akarunk érteni, akkor célszerü Magyarországot elhelyezni a közép- és kelet-európai térségben, a magországok és a periféria, tőkét és technológiát exportálók és importálók tengelyében. A térségben uralkodóknak mindenkor biztosítaniuk kell azt, hogy a kapitalista világgazdaság cserefolyamataiban oly módon legyenek képesek részt venni, hogy egyrészt a maguk számára minél elönyösebben kiaknázzák az ebben rejlö lehetőséget, másrészt stabilitást biztosítsanak a hátországban a cserefolyamat egyenlőtlen és alárendelt jellege ellenére is. A fö feladat a modernizáció biztosítása, ami inkább nem sikerül, mint sikerül. A térség a polgárosodásba való átmenetben van évszázadok óta, társadalmai a nyugaton is megkezdett folyamatok befejezetlenségétől terhesek.

Ma még közzel van hozzánk a félmúlt. A Kádár-rendszerben kiéleződő társadalmi ellentmondásokra adott lehetséges magyarázatok a modernizáció perspektívájában fogalmazhatók meg. Magyarázhatók a társadalmi folyamatok pl. regionalizmussal, vagyis a Hadas által is hivatkozott köztes Európa sokak által leírt ellentmondásos helyzetével. Hivatkozhatunk a köztes Európában élő ember kettős természetére: félig még az archaikus formák foglya, ugyanakkor a megindult polgárosodás nem hagyta érintetlenül. Musilra utalva csekély a realitásérzékünk (amiben gyöngék vagyunk, az a Wirklichkeitssinn), de gazdagok vagyunk képzeletben, sőt képzelődésben (Möglichkeitssinn), és a valóságnak ezek az egymástól objektív módon különböző síkjai gyakran zavarba ejtő módon keverednek egymással.

Az államszocializmust az állandó reformkényszer jellemzi. Már az 1921-ben kényszerüen bevezetett NEP (új gazdasági politika) annak bizonyítéka, hogy az államszocializmus, vagyis a társadalom homogenizálása az ipari forradalmat követő társadalmakban lényegében megvalósíthatatlan, ezért folytonosan fölmerülő feladat az állam és a politika által uralt, valamint a többé-kevésbé békében hagyott szektorok közötti egyensúlyozás. A reform lényege mindig a decentralizáció, a társadalom védekezése a túlhatalom következtében beálló, Kornai által Magyarországon már az ötvenes évek végén leírt túlzott központosítás ellen. Szükségszerü, hogy az alacsony hatékonysággal müködő állami szektor mellett megjelenjenek a magángazdaság félig elismert formái. A második gazdaság ugyan a polgárosulás jele, de a rendszerváltozás után kiderült: azok a formák csak a lomha állami vállalatokkal szimbiózisban voltak életképesek, valós versenyviszonyok között nem maradhattak fenn. 
A történeti magyar karakterhez, a szakszerü igazgatással szembeállítható, Erdei és Bibó által leírt úri igazgatás mögött meghúzódó dzsentri beállítottsághoz és az abból fakadó ellentmondások szemléltetéséhez jó adalék a ma sajnálatos módon reneszánszát élő Szabó Dezső. Nála a megértés és együttműködés negatív minta, amit kíméletlenül kigúnyol, szembeszegezve azt egy nietzschei, ugyanakkor nagyon kelet-európai akarattal: „Megértem! Megértem! Ez az ő modern frázisuk. A fészkes fittyfene egye meg a megértéseteket! Nekünk öklünk volt, vagy ölelésünk, ők megértenek. Megértés! Ez a modern eunuk-úrfik müfallosza!" (Szabó 1981 [1919]: 25).

Ki tudja, mikor szabadulhatunk meg a cselekvést megbénító édes-bús narratívától. Isten úgymond jelen van a történelemben, és ez az Isten ítélkezik és büntet. Az így materializált történelemben azután a magyarság csak veszít és veszít, nem kapva más lehetőséget, mint hogy eljátssza „Európa Hamupipőkéjének” szerepét:

Erős akarat, középtehetség: ez a demokrata típus, kérges szívvel és kérges arccal. A magyarnak mindig kell valaki, aki szeresse, biztatgassa, elismerje, másképp elbitangol, elzüllik. Nincs magánosabb szomorúság a világon, mint egy magyar tehetség! Miénk a vér ömlése, a bezúzott homlok, a nehéz munka birkózása s hozzánk botlott kis ügyeseké a tejfel. A magyar a világtörténelem legnagyobb balekja, és ez sohasem lesz másképp (Szabó 1981 [1919]: 62).

A demokrácia és a szabad verseny idegen a magyarnak tetsző felfogástól, holott sikeres modernizáció demokrácia és szabad verseny nélkül nem lehetséges, de anélkül sem, hogy a versenyintézményeket a társadalom ne tudja mintegy magyarítani, a maga képére formálni a magyarság történelmi tapasztalatának és tudott habitusának megfelelő módon. Ezzel szemben a Szabó Dezső által leszögezett tény: „A magyar fajt a demokrácia úgy érte, mint úszni nem tudót a hirtelen áradás. Sem múltjában, sem képességeiben, sem moráljában nem volt elkészülve a szabad versenyre" (i. m. 310).

A népi tábor tudatának jellemzéséhez fontos a sérelmi nacionalizmus kiemelése. A mélyben az a kudarcélmény húzódik meg, hogy a magyar társadalom nem volt felkészülve a 19-20. század fordulóján kialakuló korai globalizmusból adódó kihívások megválaszolására és az ebből következő feladatok kezelésére. Ebből fakad az, hogy fölerősödött az idegenségtudat. Ekkor gyökeresedik meg a fóbia mindazzal szemben, ami nem magyar, ami elöítéletekben, sőt társadalmi szokásokban is kifejeződik. Alapélmény az idegenség patologikus felnagyítása, ami demagóg antikapitalizmussal egészül ki. Ebből táplálkoznak azok a sokszor nemtelen indulatok is, amelyek pl. a nem magyar eredetü (német, cseh) polgárság magyar társadalomba való szervesülését, és különösen zsidóként megbélyegzett honfitársaink asszimilációjának folyamatát ellehetetlenítették.

A félállampárt mögött álló széles rétegek azért voltak mozgósíthatók a NER (az ún. nemzeti együttműködés rendszere) legitimálására, mert a NER híveinél a gondolkodási és cselekvési mód fontos eleme az idegenségkomplexus. Erre rárakódik a sérelmi nacionalizmus és a kíméletlen szociális kirekesztés is. Az Orbán-rendszer képes volt milliós nagyságrendben megvásárolni - pl. brutálisan igazságtalan adókedvezményekkel - olyanokat, akik a NER haszonélvezői lettek. Állam és társadalom foglyul ejtése azonban nem lett volna lehetséges a nemzedékeken keresztülhurcolt idegenségkomplexus kiaknázása nélkül.

A keresztény és nemzeti eszmék hívei a nép felemelkedését úgy képzelik el, hogy a politikai nemzetfogalom kiterjeszthető lenne a történelmi úri osztályról a magyar (pontosabban annak mondott) etnikum egészére. 
Ha önök a magyarság és kereszténység ügyét megint hozzákötik az arisztokrácia és kiváltságosok sorsához, akkor a legnagyobb emberi egység, a világtörténelem legnagyobb csodája önökben fog szétrothadni. Milyen jogon voltak történelmi osztály önök? A régi, fegyveres munka jogán. Pedig ez igen sokszor csak kaparj, kurta neked is lesz kicsinyes marakodás volt. Most egy egészen más, gigászi honfoglalás révén egyetlen egy történelmi osztály van: a magyar nép. Azt kell éppen megmutatni, hogy a kereszténység nem ellensége érdekeinek, hanem éppen a legszélesebb forma minden emberi jóság, minden jog, minden becsületes élet érvényesülésére (Szabó 1981 [1919]: 482).

Paradox módon azt látjuk, hogy az egyebek mellett Szabó Dezső által fémjelzett gondolkodásmód a feudalizmusból örökölt becsületkódexet nem a polgári erényekkel akarja felváltani, hanem a népi munkakánonnal akarja kiegészíteni, mintha át lehetne ugorni a polgári fejlödést. A népnemzeti gondolat meghirdetésével már Gyulai Pálék kísérletet tettek arra, hogy a nemzet fogalmát kiterjesszék az úri osztályról a népre egy etnikai alapú, de politikailag szervezett nemzetfogalomban - e gondolat azonban a népi írók sokszor tiszteletre méltó erőfeszítései ellenére is történelmileg súlyosan kompromittálódott a két világháború kataklizmájában és a kapcsolódó nagy nemzeti kudarcokban. Ma, újabb modernizációs kísérlet előtt állva, ismét a kiszélesítés, a társadalmasítás lehet napirenden, ami azonban a polgári erények elsajátítása nélkül bizonyosan nem lehetséges.

Lukács György szerint Szabó Dezső látja azt, hogy a kiegyezéssel létrejött hivatalos Magyarország mennyire talmi, amivel szemben az író joggal élhet radikális kritikával: „Szabó Dezső felismeri, hogy nincs igazi magyar polgárság. Felismeri, hogy ez 67 következménye. Felismeri, hogy az a hivatalos magyar kultúra, amely 67 talaján nőtt, se nem kultúra, se nem magyar, se nem nemzeti. Ez a felismerés állítja őt szembe minden uralkodó irányzattal: Tiszától a forradalmakon keresztül Bethlenig és Gömbösig" (Gróh 1981: 561-562). Az úri osztály és a hozzá idomuló polgári rétegek a kiegyezéssel felemás, félig meggondolt igazságokat kaptak elődeiktől útravalóul, és hagytak örökül utódaikra, ami miatt a közéletre egy korokon átívelő groteszk, tragikomikus folytonosság vetül rá Tiszától Bethlenen keresztül Gömbösig és Orbánig (amit érzékletesen fejez ki pl. az átalakított budapesti Kossuth tér mai állapotában).

\section{Civil politizálás}

A reformprogramok hatástalanok maradnak, ha nem sikerül civil politizálás révén feldolgozni a magyar középosztály terhes örökségét és kezelni történelmi frusztráltságát. Másként nem oldható fel az a szinte végzetes pesszimizmus, ami a modernizációs kudarcokkal terhes magyarság történetének máig érvényes alapvonása. Miközben a képviseleti demokrácia hagyományos intézményei egyre jobban kiüresednek és a politikai szereplők hiteltelenné válnak, a civil mozgalmak a közélet megújításának forrását jelenthetik. A társadalmi kohézió erősítése csak a civil élet, az alulról jövő mozgalmak, az életvilág gazdagítása révén remélhető. A civilek fontos szerepet tölthetnek be a béketeremtésben, a társadalmi kiegyezés folyamatának előmozdításában, amihez azonban meg kell találniuk a jelen lévő politikai szereplőkkel való együttműködés módjait.

Demokráciában alapfeltétel a politikai másság elfogadása. A demokratikus politizálás nem abból áll, hogy a hasonlók egymást erősítik, hanem abból, hogy a nem hasonlók felismerik egymást a különbözőségben, és lépéseket tesznek arra, hogy közös nevezöt (nyelvet, 
intézményeket) lehessen találni az együttmüködéshez. A magyar társadalom átépítésének záloga a politikai cselekvési tér kiszélesítése, a közéleti viták elmélyítése, az érzelmi ráhangolódás a tenni akarásra, és élményszerzés a közös munkában. A másféleség megtapasztalása elmélyítheti a találkozók résztvevőiben az érzékenységet, segíthet áttörni a közömbösség falát, és érzelmileg áthangolhatja azokat, akik részt vesznek a közösségépítési folyamatban.

A polgári társadalom eszményei és intézményei ma utópiának látszanak számunkra, jóllehet azzal is számot kell vetnünk, hogy a vágyott haladással bekövetkező polgári társadalom és köztársaság maga is opportunizmustól terhelt: „Az eleve utópikus társadalmi szerződésből a szabadkereskedelemre és a hatékonyság folyamatos növelésére építő társadalmak exorcista eszközökkel száműzték az utópiát. Az utópiával együtt megszűnt a múlt idö, és nincs jövő, a jelen idő lett egyeduralkodó” (Nádas 2017: 596). Mégis, a ránk toluló ellentmondások közepette is hivatkoznunk kell és lehet a nehéz időkben is épnek gondolt erkölcsi érzékünkre, ha másra nem, a kiállás bátorságára, önbecsülésünkre: „Mert ha sehol is: otthon állok / mert az a való, mit én látok, / akkor is, ha mint délibábot, / fordítva látom a világot” (Illyés Gyula, Haza a magasban; 1938).

\section{Hivatkozott irodalom}

Hadas Miklós (2017): Mi a magyar? Úratöltve - hetvennyolc év után. Replika (105): 193-211. Interneten: http:// replika.hu/replika/105-11.

Gróh D. (1981): Szabó Dezső. In Szabó Dezső: Az elsodort falu. Debrecen: Csokonai.

Mészöly Miklós (1990): 1989. március 15. In uő. A negyedik út. Esélyek és kockázatok az ezredvég küszöbén. Szombathely: Életünk Könyvek, 303-304.

Nádas Péter (2017): Világló részletek II. Budapest: Magvető. Az elsodort falu. Debrecen: Csokonai.

Szabó Dezső (1981 [1919]): Az elsodort falu. Debrecen: Csokonai. 